\title{
Four years of low dose enzalutamide for metastatic castration-resistant prostate cancer
}

\author{
Léčba kastračně rezistentního karcinomu prostaty enzalutamidem \\ trvající 4 roky
}

\author{
Natchagande G. ${ }^{1}$, Vinh-Hung V. ${ }^{2}$ \\ ${ }^{1}$ Teaching University Hospital of Cotonou, Cotonou, Benin \\ 2 University Hospital of Martinique, Fort-de-France, Martinique, France
}

\begin{abstract}
Summary
Background: The management of metastatic castration-resistant prostate cancer involves second-generation antiandrogen therapy, including enzalutamide. The recommended dose of $160 \mathrm{mg} /$ day is sometimes difficult to use in elderly patients because of the burden of comorbidities. The usefulness of a low effective dose remains unclear. Methods: We report the first ever patient, now aged 87 years, who had progressing prostate cancer and was treated at $25 \%$ of the recommended dose for over 4 years. Results: The most striking observation is that nothing extraordinary happened. The disease responded without dramatic toxicities. His follow-up has been serene on both aspects of prostate cancer and general health. Conclusion: Cautious dosage can have a long-lasting favorable impact in the elderly patient.
\end{abstract}

\section{Key words}

prostate cancer - prostatic neoplasms - castration-resistant - reduced-dose drug use treatment efficacy - treatment outcomes - enzalutamide

\section{Souhrn}

Východiska: Léčba metastatického kastračně rezistentního karcinomu prostaty zahrnuje antiandrogenní terapii, kam patři enzalutamid. U starších pacientů je někdy obtížné užívat doporučenou dávku $160 \mathrm{mg} /$ den kvưli zátěži komorbiditami. Užitečnost snížené dávky je stále nejasná. Metody: Popisujeme prípad prvního pacienta, nyní ve věku 87 let, který měl progresivní karcinom prostaty a více než 4 roky byl léčen $25 \%$ doporučené dávky. Výsledky: Nejpozoruhodnějším zjištěním je, že se nic mimořádného nestalo. Došlo k odpovědi na léčbu bez výrazné toxicity. Sledování tohoto pacienta je poklidné jak z hlediska karcinomu prostaty, tak z hlediska celkového zdravotního stavu. Závěr: Opatrné dávkování může starším pacientům přinést dlouhodobý prospěch.

\section{Klíčová slova}

karcinom prostaty - novotvary prostaty - kastračně rezistentní - užívání snížených dávek léčiva - účinnost léčby - výsledky léčby - enzalutamid
The authors declare they have no potential conflicts of interest concerning drugs, products, or services used in the study.

Autoři deklarují, že v souvislosti s předmětem studie nemaji žádné komerční zájmy.

The Editorial Board declares that the manuscript met the ICMJE recommendation for biomedical papers.

Redakční rada potvrzuje, že rukopis práce spInil ICMJE kritéria pro publikace zasilané do biomedicínských časopisů.

$\equiv$

Vincent Vinh-Hung, MD CHU Martinique, Hôpital Clarac 37 Bld Pasteur 97200 Fort-de-France Martinique

France

e-mail: vh@onco.be

Submitted/Obdrženo: 18. 7. 2020 Accepted/Prijato: 15. 9. 2020

doi: $10.48095 /$ ccko202169 


\section{Introduction}

Resistance to castration is a phase of metastatic prostate cancer that alters the patient's quality of life. Enzalutamide is an anti-androgen recommended at this stage of disease, and it has been shown to be efficient in various studies $[1,2]$. The approved dose is $160 \mathrm{mg} /$ day, corresponding to a daily dose of four tablets. Treatment with enzalutamide at this dose is often associated with side effects that can be detrimental to compliance or even tolerance of the drug, especially considering that the patients are often aged, have substantial comorbidities and receive multiple treatments with potential for adverse drug interactions [3]. The use of a minimal effective dose may be of benefit [4]. We have reported the treatment of metastatic castration-resistant prostate cancer with upfront low-dose enzalutamide, either 40 or $80 \mathrm{mg} /$ day, in 16 patients aged $\geq 75$ years [5]. The survival, the PSA control and the symptom outcomes were as good as in other younger patients from the same institution treated with $160 \mathrm{mg}$. Herein we report the precious observation of the first ever patient, which led us to reconsider the "wisdom" of a standard dose.

\section{Case presentation}

The patient, now 87 years old, gave written consent to his report. He had a history of hypertension, mitral valve replacement and use of oral anticoagulation (fluindione). He was diagnosed at the age of 64 with a Gleason 6 prostate cancer in October 1997. The PSA level was $16 \mathrm{ng} / \mathrm{mL}$. Radical prostatectomy and lymph node dissection were performed in January 1998. The histopathological diagnosis was Gleason 7 with extraprostatic extension, pT3NOMO. The post-operative PSA was $0.61 \mathrm{ng} / \mathrm{mL}$ at 1 month, increasing to $6.67 \mathrm{ng} / \mathrm{mL}$ in September 1998, and was associated with palpable local recurrence on digital rectal examination. He received radiotherapy $70 \mathrm{~Gy}$ to the prostate bed in November 1998. The PSA continued to increase up to $43.84 \mathrm{ng} / \mathrm{mL}$ in October 1999. A bone scan showed tracer uptake in the lumbar spine. He was considered metastatic. Bilateral orchiectomy was performed in December 1999 whereupon remission lasted 10 years. Biochemical recurrence was diagnosed in June 2009 with a PSA level of $2.4 \mathrm{ng} / \mathrm{mL}$, which increased to $8.70 \mathrm{ng} / \mathrm{mL}$ in February 2011. He started hormone therapy with bicalutamide. The PSA level decreased to a nadir of

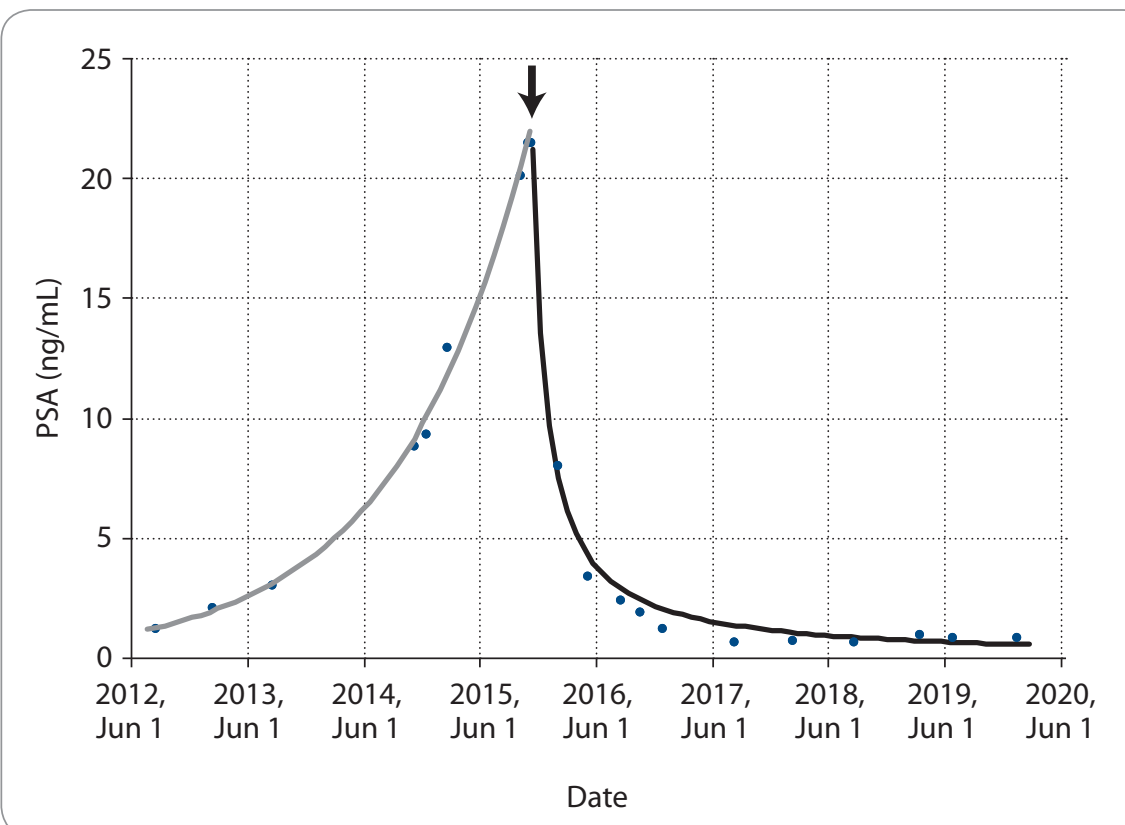

Fig. 1. PSA from Aug 2012 to Jan 2020 (full circles).

Exponential increase (grey line, fit as exponential function of time) up to start of enzalutamide 40 mg/day in November 2015 (arrow), thereafter sharp sustained drop (black line, fit as inverse function of time).
$1.25 \mathrm{ng} / \mathrm{mL}$ in August 2012 and then increased gradually. The patient was addressed through the urology multidisciplinary tumor board in October 2015 for second-generation hormone therapy. He had no complaints, except for longstanding incontinence since radical prostatectomy requiring the use of a penile sheath. Clinical examination revealed prominent bilateral gynecomastia. The spine was painless. The bone scan showed suspicious hot spots in L2 and L5. The testosterone level was $0.10 \mathrm{ng} / \mathrm{mL}$, indicating effective castration. The CT scan showed enlarged para-aortic lymph nodes. The PSA at the time was $21.47 \mathrm{ng} / \mathrm{mL}$. The progression was exponential (Fig. 1). In November 2015, bicalutamide was stopped, and the patient started enzalutamide at a dose of $40 \mathrm{mg} /$ day. The PSA level decreased to $8.07 \mathrm{ng} / \mathrm{mL}$ by the third month. A CT scan confirmed regression of the lymphadenopathies (Fig. 2). The PSA level reached a nadir of $0.72 \mathrm{ng} / \mathrm{mL}$ at 20 months and remains stable at 51 month-follow-up (Fig. 1). From November 2015 to February 2020, the clinical observation noted only a moderate intermittent oedema of the ankle treated with furosemide, varicose veins, and ochre dermatitis. There was no anticoagulation-related complication. The general condition of the patient remained stable with an Eastern Cooperative Oncology Group (ECOG) performance of 0 , without any adverse symptom.

\section{Discussion}

This case changed the way we manage elderly castration-resistant prostate cancer patients with enzalutamide. It represents a treatment paradigm shift, replacing an approach of treating first with a full dose, and reduce when toxicity arises, with an approach of treating first with a low-dose, and keep it low when the patient responds. Per the drug's legal notice, the recommendation is $160 \mathrm{mg}$ orally once daily. It states "If a patient experiences $\mathrm{a} \geq$ grade 3 toxicity or an intolerable side effect, withhold dosing for one week or until symptoms improve to $\leq$ grade 2 , then resume at the same or a reduced dose $(120 \mathrm{mg}$ or $80 \mathrm{mg})$, if warranted" [6] . The incentive is compelling to treat with the higher dose, and 


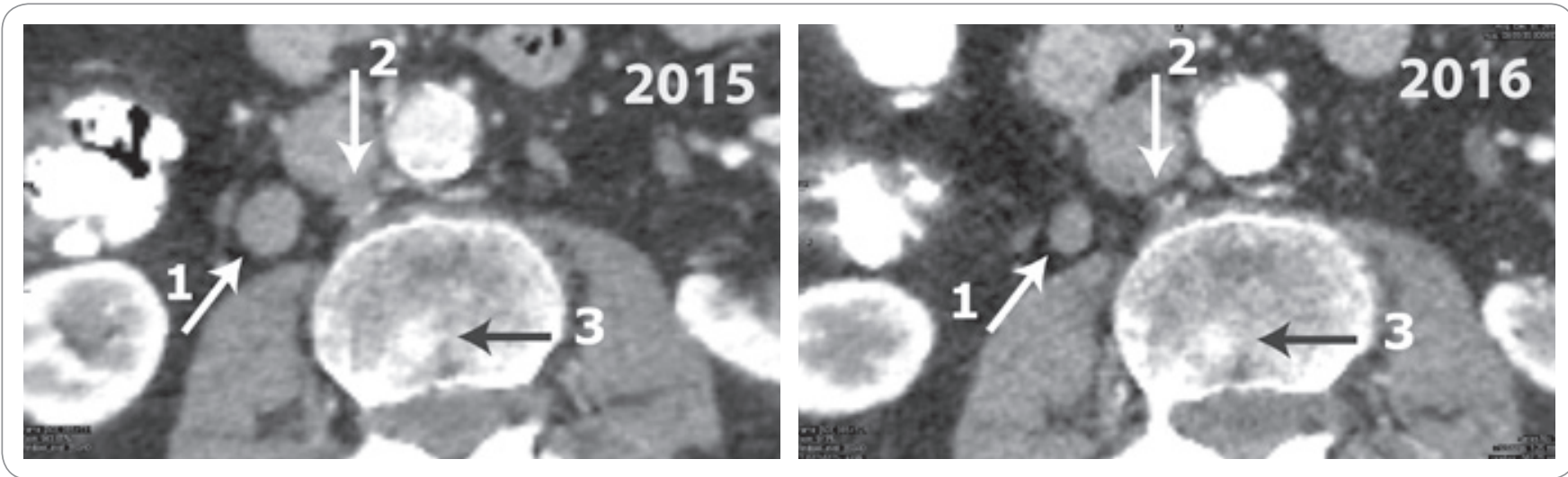

Fig. 2. Abdominal CT scan in 2015 (left panel) and 2016 (right panel).

White oblique arrow (1) - lateral vena cava lymph node, $15 \mathrm{~mm}$ in 2015, decreased to $10 \mathrm{~mm}$ in 2016. White vertical arrow (2) - retro cava, complete regression. Black horizontal arrow (3) - sclerotic bone lesion in the lumbar spine. It was considered doubtful in 2015, but regressed in 2016.

quickly resume as high as possible. However, despite the evidence that toxicity is dose-dependent [7], and despite no study demonstrates the safety of dose resumption, the toxicity-management escalates the dose even when the patient responds to a reduced dose [8]. The current literature gives no consideration to titrate the dose of enzalutamide to prevent toxicity [9]. Our case challenges the standard dose; it raises questions seldom considered in practice, why to choose a dose of $40 \mathrm{mg}$, how effective it is, and how it can help to avoid toxicities.

\section{What is a low dose?}

To date, apart scarce conference abstracts and a small series communication [5], no study has investigated low-dose enzalutamide treatment as a first-line therapy in daily practice. All randomized clinical trials that demonstrated the efficacy of enzalutamide in prostate cancer were performed at a dose of $160 \mathrm{mg}$ daily [1]. However, our patient had a long history of disease, with advancing age, intercurrent cardiovascular disease, many years of bicalutamide treatment, with mentions in the medical file of intolerance and severe gynecomastia, which contrasted with a tumor burden that was not immediately threatening on imaging. These led us to prefer a cautious approach. Therefore, we chose to start with the lowest possible dose $(40 \mathrm{mg}$ ) because it is the only small dosage available. Every time the patient was seen at follow-up, he reported that he felt good and we noted that the PSA level was decreasing. We pondered whether we should increase the dose.

In the PREVAIL trial comparing enzalutamide $160 \mathrm{mg}$ to placebo, the median age of patients receiving enzalutamide was 72 years [10]. The trial's protocol excluded patients with significant cardiac disease. The median overall survival was 35.3 months (less than 3 years) [11]. The median time to PSA progression was 11.2 months [10]. The patient's 51 month follow-up is well over the $<3$-year survival of the patients from the PREVAIL trial being younger by 10 years, and his PSA control duration is four times longer. Admittedly, there is no recent imaging. In our practice, we do not do additional imaging without symptoms and PSA progression. However, the decline in PSA observed in 3 months after the introduction of enzalutamide meets the criteria for good prognosis [12]. Despite the patient's low dose, there was radiological regression in the lymph nodes. We have no explanation for this effectiveness. Without monitoring the plasma concentration of enzalutamide and its metabolites, the potential for drug interaction, delayed metabolism or delayed elimination cannot be excluded. Regardless of the mechanism, we did not escalate the dose. Moreover, following this first case, we started treating other elderly patients with metastatic castration resistant prostate cancer with upfront low dose enzalutamide. In the series of 16 chemo- therapy-naive patients aged $\geq 75$ years treated with $\leq 50 \%$ of the recommended dose, the disease control was as good as in 43 patients receiving the standard dose [5]. At 12 weeks, $66.7 \%$ of patients treated with a low-dose reported a PSA decrease of $\geq 50 \%$, as compared with $45.0 \%$ of patients treated with a standard-dose $(P=0.152)$. The median progression-free survival was similar between the two groups (11.2 vs. 11.9 months; $P=0.612$ ). Our observation extended to subsequent patients finds comparable efficacy.

\section{Primum non nocere}

The efficacy at a low dose would be of benefit by reducing side effects and increasing compliance with the treatment. Adverse effects have been highlighted with enzalutamide and may be of greater magnitude than those reported in clinical trials. Based on randomized clinical trials, the most frequent side effects (> 10\% of patients) with enzalutamide, and exceeding a difference of $2 \%$ compared to placebo, include fatigue, anorexia, vertigo, hypertension, and weight loss [1]. Falls (10 vs. $4 \%$ ) and fractures (8 vs. $3 \%$ ) are also more frequent with enzalutamide than with placebo. Fatigue, nausea, and anorexia occurred in $39.1 \%$, $22.7 \%$, and $14.8 \%$, respectively, in an observational study of 507 patients on enzalutamide at a dose of $160 \mathrm{mg} /$ day [13]. Side effects of any grade attributed to enzalutamide affected $55.2 \%$ of patients, while 50 patients $(9.9 \%)$ had side 
effects causing death. Treatment discontinuation due to side effects can be frequent, ranging from 10 to $18 \%$, depending on the series $[4,14]$. The importance of low-dose enzalutamide in reducing side effects has been reported in a series of 345 patients, even though only $23 \%$ of the patients were started with the lower dose [4].

Apart from the side effects, the burden of comorbidities at the age when prostate cancer mainly occurs must also be considered. Enzalutamide may be responsible for the onset or worsening of comorbidities. In a meta-analysis, Zhu et al reported significant risk of developing arterial hypertension with enzalutamide [15]. In a population-based retrospective study of patients with a median age of 74-76 years with advanced prostate cancer and a history of cardiovascular disease, the authors observed that $18 \%$ of patients who did not receive chemotherapy, and $28 \%$ of those who did receive chemotherapy, died within 6 months from enzalutamide treatment initiation [16]. A study of the Eudra Vigilance database of the European Medicines Agency identified 40,599 adverse events reported for enzalutamide [17]. Over $90 \%$ of the reported adverse events were defined as serious and $18 \%$ were fatal. The analysis showed an increased overall risk of cardiac, infectious, metabolic, and respiratory disorders in elderly patients compared to those $<65$ years of age.

As briefly reviewed above, enzalutamide has been associated with disabling and fatal toxicities. In urology-oncology practice, the patients are older, less healthy, frailer, and present with more comorbidities than those included in clinical trials [5]. Typically, they are too frail to receive chemotherapy $[18,19]$, even when symptomatic [20]. Instead, they receive a second-generation antiandrogen. But, unlike the trials' selected patients who have good chances to recover from toxicities, any adverse event in the community patient can be unre- coverable and lead to the risk of early death [16]. Interestingly, there has been a case report with similar disease characteristics and concomitant receipt of fluindione [9]. He was treated with standard dose enzalutamide, experienced life-threatening complication requiring intensive care, in contrast to our patient who had over 4 years of serene follow-up on both aspects of prostate cancer and heart condition. The contrast highlights that low dose enzalutamide is a simple alternative to a standard dose, avoiding harm from potential drug's adverse outcomes [21], with the aim to maintain good quality of life and control of disease [22].

\section{Conclusion}

We describe the uncomplicated medical history of the first ever castration resistant prostate cancer patient treated at $25 \%$ of enzalutamide recommended dose; the disease has been controlled for over 4 years. Simple cautious dosage can have a long-lasting favorable impact in the elderly patient.

\section{References}

1. Sternberg CN. Enzalutamide, an oral androgen receptor inhibitor for treatment of castration-resistant prostate cancer. Future Oncol 2019; 15(13): 1437-1457. doi: 10.2217/fon-2018-0940.

2. Richter I, Dvorak J, Hejzlarova V et al. Enzalutamide and Abiraterone in the Treatment of Metastatic Castration-resistant Prostate Cancer after Chemotherapy. Klin Onko 2016; 29(2): 127-132. doi: 10.14735/amko2016127. 3. Benoist GE, van Oort IM, Smeenk S et al. Drug-drug interaction potential in men treated with enzalutamide: Mind the gap. Br J Clin Pharmacol 2018; 84(1): 122-1229. doi: 10.1111/bcp.13425

4. Terada N, Akamatsu S, Okada Y et al. Factors predicting efficacy and adverse effects of enzalutamide in Japanese patients with castration-resistant prostate cancer: results of retrospective multi-institutional study. Int J Clin Onco 2016; 21(6): 1155-1161. doi: 10.1007/s10147-016-1004-y. 5. Vinh-Hung $V$, Natchagande G, Joachim $C$ et al. Low dose enzalutamide in the late-elderly patient ( $\geq 75$ years old) presenting with metastatic castration-resistant prostate cancer. [in press]. Clin Genitourin Cancer 2020. do 10.1016/j.clgc.2020.03.019

6. Xtandi prescribing information, version 12/2019. [online]. Available from: https://www.accessdata.fda.gov/ drugsatfda_docs/label/2019/203415s015lbl.pdf.

7. Scher HI, Beer TM, Higano CS et al. Antitumour activity of MDV3100 in castration-resistant prostate cancer: a phase 1-2 study. Lancet 2010; 375(9724): 1437-1446. doi: 10.1016/S0140-6736(10)60172-9.
8. Kawahara T, Miyoshi Y, Yao M et al. The achievement of long-term CRPC control in a patient with enzalutamideinduced nausea and fatigue after overcoming the adverse events with a temporary drug holiday. Case Rep Oncol 2019; 12(2): 568-572. doi: 10.1159/000501849.

9. Strobbe G, Pannier D, Villain A et al. First-time prescription of enzalutamide in a patient treated with fluindione and digoxin: serial drug interactions. Acta Oncol 2019; 58(8): 1167-1169. doi: 10.1080/0284186X.2019.1606936. 10. Beer TM, Armstrong AJ, Rathkopf DE et al. Enzalutamide in metastatic prostate cancer before chemotherapy. N Engl J Med 2014; 371(5): 424-433. doi: 10.1056/NEJMoa1405095.

11. Beer TM, Armstrong AJ, Rathkopf D et al. Enzalutamide in men with chemotherapy-naive metastatic castration-resistant prostate cancer: extended analysis of the phase 3 PREVAIL study. Eur Urol 2017; 71(2): 151-154. doi: 10.1016/j.eururo.2016.07.032.

12. Armstrong AJ, Lin P, Higano CS et al. Prognostic association of prostate-specific antigen decline with clinical outcomes in men with metastatic castration-resistant prostate cancer treated with enzalutamide in a randomized clinical trial. Eur Urol Oncol 2019; 2(6): 677-684. doi: 10.1016/j.euo.2018.11.005

13. Joshua AM, Shore ND, Saad F et al. Safety of enzalutamide in patients with metastatic castration-resistant prostate cancer previously treated with docetaxel: expanded access in North America. Prostate 2015; 75(8): 836-844. doi: 10.1002/pros.22965.

14. Beardo P, Osman I, San Jose B et al. Safety and outcomes of new generation hormone-therapy in elderly chemotherapy-naive metastatic castration-resistant prostate cancer patients in the real world. Arch Gerontol Geriatr 2019; 82: 179-185. doi: 10.1016/j.archger.2019.02.008

15. Zhu X, Wu S. Increased risk of hypertension with enzalutamide in prostate cancer: a meta-analysis. Cancer Invest 2019; 37(9): 478-488. doi: 10.1080/07357907.2019. 1670203

16. Lu-Yao G, Nikita N, Keith SW et al. Mortality and hospitalization risk following oral androgen signaling inhibitors among men with advanced prostate cancer by pre-existing cardiovascular comorbidities. Eur Urol 2019; 77(2): 158-166. doi: 10.1016/j.eururo.2019.07.031.

17. De Nunzio C, Lombardo R, Tema $G$ et al. Adverse events related to abiraterone and enzalutamide treatment: analysis of the EudraVigilance database and meta-analysis of registrational phase III studies. Prostate Cancer Prostatic Dis 2019; 23(2): 199-206. doi: 10.1038/s41391019-0182-x.

18. Richter I, Dvorak J, Bartos J. Docetaxel-cabazitaxel-enzalutamide versus docetaxel-enzalutamide in patients with metastatic castration-resistant prostate cancer. Klin Onkol 2017; 30(4): 289-293. doi: 10.14735/amko2017 289.

19. Richter I, Dvorak J, Bartos J. Options of chemotherapy in the treatment of prostate cancer. Klin Onkol 2017; 30(1): 28-33. doi: 10.14735/amko201728.

20. Ondrus D, Ondrusova M. Management of patients with castration-resistant metastatic prostate cancer. Klin Onkol 2015; 28(1): 24-29. doi: 10.14735/amko201524.

21. Hanus M, Matouskova M, Dusek L. Prostate carcinoma. Current dilemma of urooncology. How to help the needed and not to harm the others. Klin Onkol 2013; 26(3): 170-178. doi: 10.14735/amko2013170.

22. Matouskova M. Prostate cancer. Klin Onkol 2008; 21(5): 280-287. 